\title{
Komunikasi Interpersonal Mediator Dalam Proses Mediasi Perkara Perceraian di Pengadilan Agama Tulungagung
}

\author{
Darisy Syafaah $^{\mathrm{a}, 1,{ }^{*}}$, Lismawati $^{\mathrm{b}, 2}$, \\ a Jurusan Komunikasi dan Penyiaran Islam, Fakultas Ushuluddin, Adab \& Dakwah \\ Institut Agama Islam Negeri Tulungagung,66221, Indonesia \\ ${ }^{b}$ a Jurusan Komunikasi dan Penyiaran Islam, Fakultas Ushuluddin, Adab \& Dakwah \\ Institut Agama Islam Negeri Tulungagung,66221, Indonesia \\ ${ }^{1}$ darisy.syafaah89@gmail.com; ${ }^{2}$ penulislismha8@gmail.com;
}

Riwayat Artikel:

Diterima: Januari 2019

Direvisi : Februari 2019

Disetujui: Maret 2019

Kata Kunci:

Komunikasi Interpersonal

Mediator

Proses Mediasi

Keywords:

Interpersonal Communication

Mediator

Mediation

\begin{abstract}
Abstrak:
Penelitian ini membahahas dua persoalan pokok yaitu: 1) Bagaimana komunikasi interpersonal mediator dengan pihak yang berperkara dalam proses perceraian di Pengadilan Agama Tulungagung?, 2) Faktor apa sajakah yang mendukung dan menghambat komunikasi interpersonal mediator Pengadilan Agama Tulungagung dalam proses mediasi perkara perceraian?. Metode yang digunakan peneliti untuk menjawab permasalahan tersebut adalah metode kualitatif deskriptif melalui studi kasus perceraian yang terjadi di Pengadilan Agama Negeri Tulungagung. Adapun untuk memperoleh hasil data secara rinci, penelitian ini menggunakan metode wawancara, observasi dan dokumentasi. Hasil penelitian menunjukkan bahwa 1) Mediator mengaplikasikan 5 prinsip hukum komunikasiefektif dalam melaksanakan mediasi dengan pihak yang berperkara pada kasus perceraian di pengadilan Agama Tulungagung yaitu: empati, menghormati, dapat didengarkan atau dimengerti, kejelasan pesan, dan sikap rendah hati yang ditunjukkan melalui sikap dan tutur mediator, 2) Keberhasilan mediator dalam komunikasi interpersonal untuk menekan angka perceraian di Pengadilan Agama Tulungagung disebabkan oleh sikap tegas dan netral mediator dalam mengarahkan pihak yang berperkara serta sikap pihak berperkara yang terbuka. Namun di sisi lain, komunikasi interpersonal terkadang menunjukkan keberhasilan yang rendah karena permasalahan tawar menawar yang rumit terkait harta gono gini, sikap kukuh para pihak yang berperkara untuk bercerai, serta keengganan mengikuti proses mediasi sebagai jalan untuk mempercepat proses perceraian
\end{abstract}

\section{Abstract:}

This study addresses two main issues, namely: 1) How is mediator interpersonal communication with litigants in the divorce process in the Tulungagung Religious Court?. To answer this problem, researchers used descriptive qualitative methods oriented to divorce case studies that took place in the Tulungagung District Religious Court. In order to obtain detailed data results, researchers used three methods of data collection, namely interviews, observation and documentation as nonhuman data sources. The results showed that 1) Mediators applied 5 principles of interpersonal communication in conducting mediation with litigants in divorce cases at the Tulungagung Religion court, namely: empathy, respect, can be heard or understood, clarity of messages, and a humble attitude that was shown through attitude and speech mediator, 2) The success of the mediator in interpersonal communication to reduce divorce rates in the Tulungagung Religious Court is caused by the firm and neutral attitude of the mediator in directing the litigant party and the open attitude of the litigant party.However, on the other hand, interpersonal communication sometimes shows low success because of the problem of complicated bargaining related to property, the firm attitude of the parties to divorce, and reluctance to follow the mediation process as a way to speed up the divorce process. 


\section{Pendahuluan}

Komunikasi memiliki peran penting dalam menjalin hubungan sosial dengan orang lain karena sebagai sarana untuk saling mengerti satu dengan lainnya. Cara komunikasipun cukup beragam, baik melalui kelompok kecil, maupun yang lebih besar dengan topik pembahasan dan kepentingan yang berbeda.

Dalam kondisi- kondisi tertentu, komunikasi melalui kelompok kecil atau disebut dengan komunikasi interpersonal ini biasanya digunakan. Komunikasi interpersonal bisa terjadi dalam hal yang lebih intensif dan bersifat pribadi misalnya komunikasi seseorang dengan Tuhannya. Komunikasiini juga dilakukan oleh dua orang untuk saling bertukar informasi dan memperoleh solusi dari suatu masalah. Komunikasi ini dianggap lebih efisien karena memungkinkan adanya feedback secara langsung. ${ }^{1}$

Beberapa kasus tertentu seperti kasus kenakalan remaja, komunikasi di pantai jompo, serta beberapa proses mediasi kasus peradilan banyak menggunakan strategi komunikasi interpersonal. ${ }^{2}$ Karena komunikasi interpersonal tidak hanya sebagai sarana untuk menyampaikan pesan semata tetapi berkembang menjadi sebuah landasan untuk proses pengambilan keputusan. ${ }^{3}$

Begitu juga dalam upaya proses mediasi kasus perceraian, mediator di Pengadilan Agama Negeri Tulungagung strategi ini. Sehingga para mediator harus memiliki kompetensi yang baik di bidang komunikasi interpersonal. Karena dengan adanya komunikasi interpersonal yang mumpuni diharapkan mampu membangun suasana mediasi yang baik, dan efektif dalam mengatasi hambatan- hambatan saat mediasi berlangsung.

Selama ini, penyelanggaraan proses mediasi menjadi salah satu pilihan oleh mereka yang bersengketa karena pelaksanaannya lebih luwes, tidak terlalu formal serta tidak diatur secara rinci dalam perundang- undangan. ${ }^{4}$

Kasus perceraian di Tulungagung sendiri menduduki peringkat yang tinggi dan mengalami kenaikan setiap tahunnya.Tercatat di Pengadilan Agama Negeri Tulungagung sekitar 200-400 permohonan cerai di setiap bulan dengan berbagai latar belakang masalah.

Selain itu, berdasarkan data mediasi di Pengadilan Agama Tulungagung selama periode tahun 2018, jumlah perkara yang dimediasi cerai gugat sebanyak 263 yang berhasil berjumlah 7 perkara, 23 yang berhasil sebagian perkara, dan gagal dimediasi sebanyak 233 perkara. Adapun jumlah perkara yang dimediasi jenis perkara cerai Talak sebanyak 169 perkara, yang berhasil berjumlah 2 perkara, sebagian berhasil berjumlah 29, dan untuk jumlah perkara yang gagal dimediasi sebanyak 138 perkara. ${ }^{6}$

Dengan memperhatikan beberapa kasus mediasi di atas, meskipun mediasi menggunakan azas keluwesan dan kenetralan, ternyata belum menunjukkan hasil yang begitu signifikan dalam menekan angka perceraian di Tulungagung.

Oleh karena itu, peneliti ingin mengkaji lebih mendalam bagaimana komunikasi interpersonal yang dilakukan mediator dalam proses mediasi kasus perceraian di Pengadilan Agama Tulungagung serta faktor pendukung dan penghambat proses mediasi tersebut.

\footnotetext{
${ }^{1}$ Wiryanto, Pengantar Ilmu Komunikasi (Jakarta: Grasindo: 2014), 32.

${ }^{2}$ Gulam, Studi Komunikasi Interpersonal dalam Keluarga Guna Mencegah Kenakalan Remaja di Kelurahan Baru Ulu Kecamatan Balikpapan(Jurnal Ilmu Komunikasi, 2016), 577. Lihat juga tulisan Cristanty M, Azeharie S. Studi Komunikasi Interpersonal Antara Perawat dengan Lansia di Pantai Lansia Anta Anna Teluk Gong) Jakarta Jurnal Komunikasi Februari 2017, Vol 2, hal. 170. lihat juga SkripsiAyu Mas'udah, Efektifitas Tugas Lembaga Mediasi dalam Menyelesaikan Perkara di Pengadilan Agama Sidoarjo (Perspektif Perma RI No. 2 Tahun 2003), Uin Maulana Malik Ibrahim tahun 2002

${ }^{3}$ Arni Muhammad, Komunikasi Organisasi (Jakarta: PT Bumi Aksara, 2004). 158

${ }^{4}$ Takdir Rahmadi, Mediasi (Jakarta: PT. Raja Grafindo Persada, 2011). 21

5 Destyan H. Sujarwoko “ Angka Perceraiain di Tulungagung Tinggi“ dalam Antaranews.com edisi senin 9 oktober 2017 (https://jatim.antaranews.com/berita/206865/angka-perceraian-di-tulungagung-tinggi)

${ }^{6}$ Dokumen Pembukuan Pengadilan Agama Tulungagung tahun 2019
} 


\section{Kajian Pustaka}

\section{A. Komunikasi Interpersonal}

Komunikasi interpersonal (Interperson Communication), adalah proses komunikasi dengan diri sendiri atau individual. Bentuk komunikasi seperti inijuga bisa terjadi antara dua orang atau lebih untuk saling bertukar informasi dan memperoleh respon secara langsung. ${ }^{7}$

Adapun ciri- ciri komunikasi interpersonal adalah: 1) terjadi arus komunikasi dua arah antara komunikator dan komunikan dimana mereka bisa saling bertukar peran 2) komunikasi bersifat non formal dan secara lisan, 3) komunikasi berada pada jarak dekat dan bertatap muka secara langsung, 4) komunikasi pesan terjadi secara spontan baik menggunakan bahasa maupun isyarat. ${ }^{8}$

Komunikasi interpersonal memiliki beberapa tujuan di antaranya adalah sebagai upaya untuk memahami diri- sendiri, memahami dunia luar melalui pemahaman karakter diri sendiri dan dan lawan bicara kita, menjalin dan memelihara hubungan dengan orang lain sehingga bisa mengurangi beban persoalan yang dirasakan, mengubah sikap orang lain, memperoleh hiburan serta membantu para psikologis untuk mengarahkan kliennya.

Fungsi komunikasi interpersonal secara umum adalah sebagai upaya untuk meningkatkan hubungan insani, menyelesaikan persoalan antarpersonal, meyakinkan seseorang terhadap sesuatu, serta sebagai media untuk saling bertukar pengalaman dan pengetahuan. ${ }^{9}$

\section{B. Prinsip-Prinsip Komunikasi Interpersonal}

Efektifitas komunikasi interpersonal dapat dijelaskan limaprinsip hukum komunikasi efektif. Lima hukum itu yang meliputi Respect, Empathy, Audible, Clarity, dan Humble yang disingkat "REACH".Prinsip- prinsip tersebut dapat dijabarkan sebagai berikut:

1) Respect ialah sikap menghargai terhadap komunikan atau orang yang menjadi sasaran pesan kita.

2) Empathy (empati) adalah memiliki kemampuan untuk menempatkan diri pada kondisi yang dialami oleh seseorang.

3) Audible berarti komunikan bisa menerima pesan yang disampaikan oleh lomunikator.

4) Clarity atau kejelasan pesan, yaitu tidak memunculkanmulti interpretasi atau penafsiran yang berbeda dari pesan tersebut.

5) Humble yaitu: mampu mewujudkan komunikasi interpersonal yang efektif melalui sikap rendah hati.

\section{Mediasi}

Mediasi berasal dari kata "mediation" yang memiliki maknacara penyelesaian perselisihan dengan nuansa sosial dan legal. Dalam mediasi terdapat seorang mediator yaitu pihak yang netral yang bertugas memberikan bantuan prosedural dan substansi. ${ }^{10}$

Unsur-unsur dalam mediasi adalah sebagai berikut: 1)penyelesaian perselisihan atau sengketa dilakukan melalui perundingan berdasarkan pendekatan mufakat atau konsensus para pihak, 2) adanya mediator yang bersikap netral, 3) mediator hanya berperan sebagai pihak yang membantu menyelesaikan masalah para pihak yang berselisish dan tidak memiliki hak untuk memutuskan.

${ }^{7}$ Hafied Canggara, Pengantar Ilmu Komunikasi,(Jakarta: PT Raja Grafindo, 2004),36

${ }^{8}$ Karningtyas MA. Pola Komunikasi Interpersonal Anak Autis di Sekolah Autis Fajar Nugraha Yogyakarta. Jurnal Ilmu Komunikasi. 2014 Jan 29;7

${ }^{9}$ Hafied Canggara, Pengantar Ilmu ...., 33

${ }^{10}$ Herri Swantoro, Strategi dan Taktik Mediasi (Jakarta: Prenamedia Group, 2016), 52-54 
Mediasi penyelesaian ini dapat dicapai jika seluruh pihak yang berselisih bisa menerima sehingga mediasi berakhir dengan jalan buntu (deadlock, stalemate). ${ }^{11}$

Proses mediasi diatur oleh PERMA No. 1 Tahun 2008 yaitu tentang prosedur mediasi yang mewajibkan pihak penggugat dan tergugat dalam perkara perdata untuk terlebih dahulu menempuh proses mediasi sebelum pokok perkara diputus oleh hakim di pengadilan tingkat pertama.Selain itu mediasi juga berlandaskan pancasila sila keempatyaitu "Kerakyatan yang Dipimpin oleh Hikmat Kebijaksanaan dalam Permusyawaratan/Perwakilan”.

Prosedur mediasi dilakukan melalui tahapan- tahapan berikut, yaitu: 1) Tahap pra mediasi, pada tahap ini para pihak yang bersengketa diwajibkan untuk mengikuti proses mediasi yang prosedurnya sudah dijelaskan oleh hakim 2) Tahap proses mediasi: dimana pada tahap ini resum perkara para pihak sudah masuk kepada mediator 3) Proses mediasi yang menghasilkan kesepakatan perdamaian atau gagal mencapai kesepakatan perdamaian, 4) kegagalan pada proses mediasi menghasilkan perdamaian 5) Prosedur pengulangan mediasi, yaitu adanya peluang kembali untuk menempuh mediasi setelah kegagalan mediasi tahap awal. ${ }^{12}$

\section{Perceraian}

Perceraian berasal dari kata cerai yang mendapat awalan "per"sebagai pembentuk kata benda abstrak sehinggamenjadi perceraian yang memiliki makna hasil perbuatan cerai atau pisah.13

Perceraian adalah berakhirnya hubungan antara suami dan istri akibat putusnya ikatan antara keduanya. ${ }^{14}$

Konsep "perceraian" diatur dalam Pasal 38 Undang-undang Nomor 1 Tahun 1974 tentang Perkawinan adalah perceraian karena talak. Hal ini berbeda dengan konsep "perceraian" dalam Undang-undang Nomor 7 Tahun 1989 tentang Peradilan Agama sebagaimana diubah dengan Undang-undang Nomor 3 Tahun 2006 dan perubahan kedua dengan Undang-undang Nomor 50 Tahun 2009 yang memperluas konsep perceraian bahwa perceraian terdiri dari perceraian karena talak atau disebut juga cerai talak dan gugatan perceraian atau disebut juga cerai gugat. ${ }^{15}$

Perkawinanyang putus karena perceraian adalah perkawinan secara Islami yang putus atas kehendak suami ataudisebut talak. Tata cara perceraian yang diajukan suami diatur lebih lanjut dalam peraturan pemerintah Nomor 9 Tahun 1975 tentang Pelaksanaan Undang-undang Nomor 1 Tahun 1974 tentang Perkawinan pada Pasal 14 sampai dengan Pasal 18.

Perkawinan putus atas keputusan pengadilan adalah gugatan perceraian sebagaimana diatur dalam Pasal 40. Tata cara gugatan perceraian yang diajukan suami atau istri diatur lebih lanjut dalam Peraturan Pemerintah Nomor 9 Tahun 1975 tentang pelaksanaan Undang-undang Nomor 1 Tahun 1975 tentang Perkawinan pada Pasal 20 sampai dengan Pasal 34.

Bentuk- bentuk perceraian dalam Islam sendiri bermacam- macam seperti : 1) Talak yakni memutuskan hubungan pernikahan dengan menggunakan lafaz talak yang diucapkan oleh suami, 2) Khulu' yaitu putusnya perkawinan dengana menggunakan uang tebusan melalui ucapan talak atau khulu', 3) Fasakh yaitu putusnya hubungan perkawinan atas permintaan salah satu pihak karena merasa tertipu terhadap hal yang tidak diketahui sebelumnya ${ }^{16}$, 4) Ila' yaitu: perceraian yang terjadi akibat sumpah suami untuk tidak menggauli istrinya 5) Zhihar yaitu: sumpah seorang

\footnotetext{
${ }^{11}$ Takdir Rahmadi, Mediasi ( Jakarta: PT Raja Grafindo Persada, 2011), 12.

${ }^{12} \mathrm{Ibid}, \ldots, 183$

${ }^{13}$ Aris Bintania, Hukum Acara Peradilan Agama (Jakarta: PT Raja Grafindo Persada, 2012), 159

${ }^{14}$ Ropaun Rambe, Hukum Acara Perdata Lengkap (Jakarta:Sinar Grafika, 2002), 16

${ }^{15}$ Mustofa Sy, Dualisme Kewenangan Pencatatan Perceraian (Malang: Intelegensia Media,2015), 88

${ }^{16}$ Muhammad Syaifuddin, Sri Turatmiyah, Hukum Perceraian (Jakarta: Sinar Grafika, 2013), 37.
} 
suami yang menyamakan istrinya dengan punggung ibunya, 6) Li'an yaitu tuduhan suami atas perbuatan zina yang dilakukan istrinya tanpa adanya empat orang saksi.

\section{Metode Penelitian}

\section{A. Bentuk Penelitian}

Penelitian ini merupakan penelitian kualitatif deskriptif yang menghasilkan data berupa katakata tertulis atau lisan dari orang dan obyek yang diamati. ${ }^{17}$

Adapun jenis penelitian yang digunakan adalah studi kasus, yaitu melakukan pengujian secara rinci terhadap objekyang diamati yangmenyimpan dokumen atau peristiwa.

\section{B. Objek Penelitian dan Instrumen Penelitian}

Proses mediasi kasus perceraian dengan menggunakan komunikasi interpersonal di Pengadilan Agama Tulungagung menjadi obyek penelitian ini. Sehingga penelitian ini fokus pada proses mediasi para pihak yang berperkara dalam kasus perceraian. Dalam hal ini, peneliti sendiri sebagai instrumen utama dalam proses pengambilan, pengolahan serta uji validitas data

\section{Sumber Data}

Sumber data pada penelitian ini meliputi sumber data primer dan sumber data sekunder.Sumber data primer diperoleh peneliti secara langsung melalui informan dengan cara melakukan penelitian di lapangan yaitu para mediator di Pengadilan Agama Tulungagung, Humas Sekaligus Hakim, para pihak (penggugat dan tergugat yang melaksanakan mediasi) sekaligus orang yang terkait dengan mediasi pada perkara perceraian di Pengadilan Agama Tulungagung.

Adapun data sekunder diperoleh melalui dokumen milik Pengadilan Agama Tulungagung, seperti laporan dari pihak yang berperkara yang diterima dan diputus, laporan mediasi Pengadilan Agama Tulungagung serta data-data lain.

\section{Teknik Pengumpulan Data}

Penelitian ini menggunakan teknik pengumpulan data melalui wawancara, observasi dan dokumentasi.Teknik wawancara dan observasi digunakan untuk mempermudah interaksi antara peneliti dan obyek yang diteliti.Adapun dokumentasi digunakan sebagai data pelengkap dari datadata yang dibutuhkan. Wawancara dilakukan dengan mengajukan pertanyaan terkait fokus masalah penelitian.

\section{E. Teknik Analisis Data}

Setelah semua data dari lapangan terkumpul baik data yang bersumber dari hasil wawancara, observasi maupun dokumentasi langkah selanjutnya adalah mengolah dan menganalisis data dengan cara mereduksi data (proses pemilihan dan pemusatan data), kemudian menyusun data dalam bentuk yang sistematis sehingga menjadi bentuk yang lebih sederhana dan mudah untuk dipahami. Kemudian data diverifikasi untuk ditarik kesimpulan.

\section{F. Tempo Penelitian}

Penelitian ini dilakukan selama lima bulan mulai dari bulan Februari samapi bulan Juli 2019

\footnotetext{
${ }^{17}$ Imron Arifin, Penelitian Kualitatif dalam Ilmu-Ilmu Sosial dan Keagamaan (Malang: Kalimasada Press, 1996), 13.
} 


\section{Penyajian dan Analisis Data}

\section{A. Penyajian Data}

\section{1) Proses Mediasi di Pengadilan Agama Tulungagung}

Proses mediasi kasus perceraian di Pengadilan Agama Tulungagung dibantu oleh pihak yang disebut mediator. Seorang yang disebut mediator harus memiliki persyaratan atau kualifikasi tertentu yang dianggap mempunyai kemampuan untuk menjadi seorang mediator pada mediasi di pengadilan. 18

Mediator di Pengadilan Agama Tulungagung merupakan individu yang memiliki pendidikan strata satu atau lebih dan telah mempunyai sertifikat mediator yang diterbitkan oleh MahkamahAgung atau lembaga yang telah memperoleh akreditas dari Mahkamah Agung seperti Asosiasi Mediator Indonesia (AMINDO) yang menyatakan bahwa seseorang telah lulus dalam mengikuti pelatihan sertifikat mediasi.

Mediator ini memiliki tugas sebagai berikut: 1) Sebagai katalisator dalam penyelesaian sengketa perceraian atau narahubung para pihak yang bersengketa untuk mencari solusi secara damai, 2)memberikan pendidikan dalam mencari solusi kasus perceraian melalui nasehat dan pemahaman terhadap persoalan yang dialami 3) sebagai penerjemah keinginan- keinginan para pihak dan penyelesaian sengketa perceraian, 4) menggali informasi dari pihak yang bersengketa guna memperoleh jalan keluar yang tepat 5) guna menciptakan komunikasi yang efektif mediator harus siap disalahkan ketika mereduksi informasi atau berita yang negatif 6) menjelaskan serta memberikan pemahan terkait perselisihan yang dihadapi oleh para pihak yang bersengketa 7) menjaga iklim yang kondusif ketika proses mediasi sedang berlangsung guna menghindari perdebatan dalam penyelesaian masalah.

Berikut ini tahapan- tahapan dalam proses mediasi di Pengadilan Agama Tulungagung

a) Sidang Pra Mediasi

Pelaksanaan sidang pra mediasi ditentukan dan disesuaikan dengan kesepakatan kedua pihak. Dalam tahapan ini majelis hakim menjelaskan kewajiban para pihak dalam proses mediasi serta prosedur yang harus dilaluinya sesuai dengan PERMA No. 01 Tahun 2016 tentang Prosedur Mediasi di Pengadilan.

Apabila dalam proses mediasi, para pihak tidak datang, maka mediasi ditangguhkan. Dan mediasi dianggap gagal apabila sampai dua kali panggilan para pihak tidak hadir.

b) Laporan Mediasi

Mediator memiliki kewajiban untuk menyusun laporan mediasi yang berhasil maupun mediasi yang gagal.Laporan ini kemudian disampaikan kepada panitera sidang sebelum persidangan dimulai. Apabila laporan mediasi menyatakan gagal maka majelis hakim akan menentukan jadwal sidang berikutnya untuk dilaksanakan sidang baru. Akan tetapi jika jadwal sidang belum ditentukan maka akan dilaksanakan pemanggilan para pihak berperkara terlebih dahulu untuk menentukan jadwal sidang yang baru

c) Sidang Lanjutan Laporan Mediasi

Terdapat dua komponen dalam sidang yaitu mediasi gagal atau mediasi berhasil. Jika mediasi berhasil kedua belah pihak harus melaksanakan amar dari hasil mediasinya.Namun jika proses mediasi gagal maka akan dilanjutkan ke persidangan sampai ada keputusan dari hakim yang memeriksa perkara. 


\section{2) Pelaksanaan Komunikasi Interpersonal Mediator Pengadilan Agama Tulungagung dalam} Proses Mediasi Perkara Perceraian

Komunikasi interpersonal mediator Pengadilan Agama Tulungagung dalam proses mediasi perkara perceraian dengan para pihak berpekara menggunakan hukum komunikasi efektif sebagai berikut:

a) Empathy (Empati)

Sikap empati ditunjukkan mediator melalui kemampuannya untuk menempatkan diri pada situasi yang dialami oleh pihak yang berperkara. Syarat utama dalam berempati adalah mediator mampu mendengarakan dan juga memahami para pihak berperkara yang terkadang memiliki tingkat emosional yang tinggi .Mediator harus bersikap netral sebagai pihak yang memahami dan mendengarkan para pihak yang berperkara.

b) Audible (Dapat didengarkan atau dimengerti)

Sikap audible mediator ditunjukkan melalui penyampaian pesan dengan cara yang baik dan mudah dimengerti. Mediator sebagai pihak yang memberikan nasihat dengan bahasa yang jelas dan mampu membuat para pihak yang berperkara tersugesti untuk mengikutinya.

\section{c) Clarity (Kejelasan dari Pesan)}

Mediator menjelaskan kejelasan perkara kepada pihak yang berperkara saat proses mediasi berlangsung serta memberikan solusi- solusi yang mengarah pada perdamaian antara kedua belah pihak yang ingin bercerai.

\section{d) Humble (Sikap Rendah Hati)}

Sikap rendah hati mediator ditunjukkan melalui sikap ramah, tenang, menghargai pendapat para pihak yang berperkara dan menampung aspirasi mereka .

\section{e) Opennes (Keterbukaan)}

Seorang mediator harus menerima masukan atau umpan balik dari pihak yang berperkara dan berupaya untuk menyampaikan informasi penting kepada mereka.

Sikap terbuka mediator kepada para pihak berperkara ditunjukkan dengan memberikan kebebasan kepadamereka untuk menentukan jadwal mediasi dan pemanfaatan waktumediasi dengan sebaik mungkin serta memberikan wawasan kepada para pihak berperkara, jika adanya penundaan mediasi yang diminta langsung oleh pihak berperkara maka mediator harus bersedia mengikuti jalan penundaan mediasi.

3) Faktor yang Mendukung dan Menghambat Komunikasi Interpersonal Mediator Pengadilan Agama Tulungagung dalam Proses Mediasi Perkara Perceraian

Salah satu faktor mendasar yang mendukung tercapainya perdamaian pada proses mediasi kasus perceraian di Pengadilan Agama Tulungagung adalah i'tikad baik para pihak berperkara.

Kerjasama dari para pihak berperkara dalam penyelesaian sengketa melalui sikap kooperatif ketikaberkomunikasi secara langsung mengenai permasalahannyadi ruangan mediasi ini sangat membantu proses mediasi.

Akan tetapi mediasi juga tidak selamanya berjalan dengan lancar, hal ini disebabkan oleh beberapa hal sepertitidak adanya i'tikad yang baik dan keyakinan yang kuat para berperkara dan lebih memilih jalanperceraian sebagai jalan yang terbaik.

\section{B. Analisis Data}

1) Komunikasi Interpersonal Mediator dengan Para Pihak yang berperkara di Pengadilan Agama Tulungagung 
Komunikasi interpersonal dianggap sebagai komunikasi yang efisien dalam mengubah sikap dan perilaku.Karena dalam komunikasi interpersonal proses komunikasi dilakukan dengan tatap muka secara langsung sehingga terjadilahkontak pribadi antara komunikator dan komunikan.

Sebuah komunikasi bisa dikatakan efektif jika mengikuti lima prinsip hukum komunikasi sebagaimana yang dikutip dari Muhammad Mufid berikut: ${ }^{19}$

1) Empati ( Empathy ) yaitu sikap seseorang yang mampu menempatkan diri pada situasi yang dialami oleh orang lain

2) Menghormati (Respect) yaitu sikap menghargai seseorang yang menjadi obyek dari pesan yang kita sampaikan.

3) Dapat dimengerti (audible) yaitu informasi yang disampaikan langsung oleh komunikator dapat didengar oleh komunikan dengan yang baik, dengan tujuan untuk mengacu kemampuan komunikator dalam menyampaikan pesan atau informasi.

4) Kejelasan Pesan (Clarity)yaitu pesan yang jelas yang tidak menimbulkan penafsiran yang bermacam- macam.

5) Sikap Rendah Hati (Humble) yaitu sikap yang mendasari aspek- aspek hukum komunikasi efektif, karena dengan sikap rendah hati maka akan memupuk sikap untuk saling menghargai.

Proses mediasi bukanlah hal yang mudah. Peran mediator juga ikut andil dalam menentukan gagal tidaknya sebuah mediasi.Karena kita ketahui begitu banyak pengajuan kasus perceraian di Pengadilan Agama Tulungagung yang mengalami kenaikan setiap bulannya. Sehingga diperlukan strategi komunikasi efektif dari mediator untuk melakukan upaya mediasi dengan harapan mediasi tersebut menghasilkan sebuah mediasi yang berhasil.

Komunikasi interpersonal dengan menggunakan strategi komunikasi efektif menurut para mediator di Pengadilan Agama Tulungagung merupakan media untuk melakukan komunikasi dengan para pihak berperkara.

Seorang mediator harus memiliki kemampuan mendengarkan dan mengerti terlebih dahulu sebelum mereka didengarkan dan dimengerti.Karena sikap empati mediator harus muncul secara tepat agar komunikasi menjadi lebih berarti. ${ }^{20}$ Sikap empati mediator ditunjukkan melalui ekspresi wajah dan gerak-gerik yang sesuai, dan pehatian, serta kedekatan secara langsung pada saat yang berperkara menceritakan atau mengungkapkan permasalahannya.Sehingga mampu menyentuh psikologis masing-masing pihak yang berperkara dalam kasus perceraian di Pengadilan Agama Tulungagung.

Selain itu, sikap menghargai dan menghormati para mediator terhadap para pihak berperkara merupakan satu hal yang penting yang harus ada dalam komunikasi interpersonal dengan mengingat bahwa kerjasama yang terjalin lahir dari sikap menghargai itu sendiri. Sehingga para pihak berperkara tidak berlaku kasar terhadap mediator baik itu ucapan maupun tindakan ketika mediasi itu sedang berlangsung, serta bersedia mendengarkan dengan seksama ketika mediator di Pengadilan Agama Tulungagung berbicara kepada para pihak yang berperkara.

\footnotetext{
${ }^{19}$ Muhamad Mufid, Etika Filsafat dan Komunikasi (Jakarta: Kencana, 2009), 136.

${ }^{20}$ Ishak Mad Shah, Kepemimpinan dan Hubungan Interpersonal dalam Organisasi (Malaysia: Johor Darul Tazim, 2006), 5.
} 
Mediasi yang berlangsung di Pengadilan Agama Tulungagung dalam hal perkara perceraian merupakan proses komunikasi secara primer yang artinya bahwa proses penyampaian pesan oleh mediator kepada para pihak berperkara dengan pengaplikasiannya menggunakan symbol (lambang) sebagai media. Dalam proses mediasi mediator menyesuaikan bahasa yang digunakan dengan bahasa yang dipakai oleh para pihak yang berperkara. Hal ini dilakukan agar pihak yang berperkara merasa mudah untuk berkomunikasi dalam penyampaian permasalahan kepada mediator.

Hal ini bisa dilihat pada saat proses mediasi berlangsung di ruang mediasi Pengadilan Agama Tulungagung, adanya respon balik antara para pihak berperkara dengan mediator ketika sedang berkomunikasi.

Meskipun pada praktiknya, mediator Pengadilan Agama Tulungagung banyak berhadapan dengan para pihak yang berperkara dengan latar belakang sikap, kepribadian yang berbedabedaserta memiliki egoism yang tinggi untuk bercerai, tidak menjadi penghalang bagi para mediator untuk menyatukan kembali kedua belah pihak yang berperkara dan mencari solusi atas perkara tersebut.

Salah satu kewajiban mediator di Pengadilan Agama Tulungagung adalah menyampaikan solusi yang jelas kepada pihak berperkara. Walaupun terkadang berakhir dengan perceraian akan tetapi kesempatan kedua tetap diberikan guna menjelaskan masing-masing alasan atau inti permasalahn yang terjadi, oleh karena itu adanya seorang mediator yang menjembatani antara keduanya dari permasalahan yang terjadi sehingga dari pihak berperkara suami dan istri bisa selesai dengan baik.

Seorang mediator juga harus menunjukkan sikap rendah hati.Tidak sombong, tegas dalam mengambil keputusan antara kedua belah pihak yang berperkara. Sikap ini ditunjukkan ketika sebelum mediasi berlangsung mediator di Pengadilan Agama Tulungagung mempersilahkan para pihak berperkara untuk duduk, dan mengingatkan para pihak berperkara yang sedang emosi dengan cara yang santun dan bisa memposisikan situasi yang ada.

\section{2) Faktor Pendukung dan Penghambat Komunikasi Interpersonal Mediator dalam Proses Mediasi Perkara Perceraian di Pengadilan Agama Tulungagung}

Ada beberapa faktor yang mendukung komunikasi interpersonal mediator dalam proses mediasi perkara Perceraian di Pengadilan Agama Tulungagung yaitu: Mediator di Pengadilan Agama Tulungagung sangat tegas dalam mengarahkan berperkara untuk menjelaskan proses perceraian sesuai dengan prosedur. Selain itu, sikap netral mediator yang berusaha menjembatani kedua belah pihak yang berperkara sehingga tidak ada lagi permasalahan yang ditutupin dari keduanya.

Sikap mediator yang mengutamakan aspek keterbukaandalam memberikan pemahaman dengan menjelaskan tentang proses mediasi serta sikap terbuka dari para pihak berperkara dalam mengungkapkan permasalahan yang mereka hadapi juga menjadi aspek pendukung dalam proses mediasi.

Dan yang tak kalah penting adalah sikap empati, dukungan, dan sikap positif mediator dalam menciptakan rasa nyaman bagi pihak berperkara yang memiliki berbagai karakter yang berbeda untuk berkomunikasi secara kooperatif. Melalui hal ini akan memunculkan i'tikad yang baik dari para pihak berperkara untuk menyelesaikan masalahnya.

Meskipun demikian, proses mediasi di Pengadilan Agama Tulungagung masih menunjukkan tingkat keberhasilan yang rendah yang disebabkan oleh beberapa faktor. Pertama, di Pengadilan Agama Tulungagung perkara yang didominasi dengan masalah perceraian tidak bisa diselesaikan dengan menggunakan tawar menawar seperti penyelesaian barang.Kedua, banyak yang berkesimpulan bahwa perceraian merupakan jalan satu-satunya untuk menyelesaikan masalah rumah tangga. Ketiga, para pihak telah berdiskusi dan berusaha didamaikan oleh pihak keluarga namun tidak ada hasil sehingga dimediasi dengan cara apapun mereka tetap kukuh dengan 
pendirian. Keempat, adanya pihak ketiga baik pihak yang berasal dari kalangan keluarga maupun seorang yang menyarankan untuk tidak mengikuti proses mediasi dengan dalih agar proses mereka cepat selesai.

\section{Kesimpulan}

Temuan Penelitian ini menunjukkan bahwasanya: 1)Para mediator di Pengadilan Agama Tulungagung ketika melaksanakan mediasi dengan pihak berperkara dalam proses perceraian menggunakan 5 (lima) prinsip hukum komunikasi efektif dalam komunikasi interpersonalnya yaitu: Empathy, Respect, Audible, Clarity, dan Humble, 2) Komunikasi interpersonal mediator dengan para pihak berperkara di Pengadilan Agama Tulungagung tidak selalu menunjukkan keberhasilan. Hal ini disebabkan adanya faktor pendukung dan penghambat dalam proses mediasi. Faktor-faktor pendukung dalam proses mediasi yaitu kenetralan dari seorang mediator itu sendiri, kemampuan intelektual mediator dan kredibilitas mediator, serta kerjasama yang berjalan dari para pihak berperkara. Sedangkan untuk faktor penghambatnya yaitu adanya keyakinan yang kuat tertanamkan dari para pihak yang berperkara untuk bercerai.

\section{DAFTAR PUSTAKA}

Aris Bintania, Aris. 2012. Hukum Acara Peradilan Agama, Jakarta: PT Raja Grafindo Persada

Canggara, Hafied. 2004. Pengantar Ilmu Komunikasi,Jakarta : PT Raja Grafindo

Dokumen Pembukuan Pengadilan Agama Tulungagung tahun 2019

Gulam. 2016.Studi Komunikasi Interpersonal dalam Keluarga Guna Mencegah Kenakalan Remaja di Kelurahan Baru Ulu Kecamatan Balikpapan (Jurnal Ilmu Komunikasi,

H. Sujarwoko, Destyan“ Angka Perceraiain di Tulungagung Tinggi " dalam Antaranews.com edisi senin 9 oktober 2017 (https://jatim.antaranews.com/berita/206865/angka-perceraian-ditulungagung-tinggi)

Karningtyas. 2014. Pola Komunikasi Interpersonal Anak Autis di Sekolah Autis Fajar Nugraha Yogyakarta. Jurnal Ilmu Komunikasi

M. Cristanty dan Azeharie S. 2017. Studi Komunikasi Interpersonal Antara Perawat dengan Lansia di Pantai Lansia Anta Anna Teluk Gong) Jakarta; Jurnal Komunikasi

Mad Shah, Ishak. 2006. Kepemimpinan dan Hubungan Interpersonal dalam Organisasi Malaysia:Johor Darul Tazim, 2006

Mufid, Muhammad.2009. Etika Filsafat dan Komunikasi, Jakarta: Kencan

Muhammad, Arni. 2004. Komunikasi Organisasi, Jakarta: PT Bumi Aksara

Rahmadi, Takdir. 2011. Mediasi, Jakarta: PT. Raja Grafindo Persada

Rambe,Ropaun. 2002. Hukum Acara Perdata Lengkap, Jakarta: Sinar Grafika

Swantoro, Herri. 2016. Strategi dan Taktik Mediasi, Jakarta: Prenamedia Group

Sy, Mustofa. 2015. Dualisme Kewenangan Pencatatan Perceraian, Malang: Intelegensia Media

Syaifuddin, Muhammad dan Sri Turatmiyah. 2013. Hukum Perceraian, Jakarta: Sinar Grafika

Arifin, Imron. 1996. Penelitian Kualitatif dalam Ilmu-Ilmu Sosial dan Keagamaan Malang: Kalimasada Press

Usman, Rachmadi. 2012. Mediasi Di Pengadilan, Jakarta: Sinar Grafika

Wiryanto.2014.Pengantar Ilmu Komunikasi, Jakarta: Grasindo 